\title{
Household conditions, eczema symptoms and rhinitis symptoms: relationship with wheeze and severe wheeze in children living in the Polokwane area, South Africa
}

\author{
Janine Wichmann ${ }^{1}$, Jacqueline E. Wolvaardt ${ }^{1}$, Chantelle Maritz ${ }^{1}$ and Kuku V. V. Voyi ${ }^{1}$ \\ (1) School of Health Systems and Public Health, Health Sciences Faculty, University of Pretoria, P.O. \\ Box 667, Pretoria, 0001, South Africa \\ Janine Wichmann \\ Email: janine.wichmann@up.ac.za \\ URL: http://shsph.up.ac.za
}

\begin{abstract}
Background This is the fifth study that applied the International Study of Asthma and Allergies in Childhood (ISAAC) methodology in the Southern African Development Community (SADC region). However, it is the first ISAAC study that focused on 6- to 7-year-old children living in South Africa and that also investigated the association between potential risk factors and asthma symptoms. Objective To assess the 12-month prevalence of wheeze and severe wheeze along with their potential risk factors. Setting Within a $60-\mathrm{km}$ radius from the Polokwane city centre, Limpopo Province. Methods The survey was conducted during August 2004 and February 2005.

Parents/guardians of 6- to 7-year-old children completed the questionnaires in English, Afrikaans or North-Sotho. However, the statistical analyses were restricted to the North-Sotho group $(n=2,437)$. Results The 12-month prevalence rates of wheeze and severe wheeze were $11.2 \%$ and $5.7 \%$, respectively. The 12-month prevalence rates of eczema symptoms and rhinoconjunctivitis symptoms were $8.0 \%$ and $7.3 \%$, respectively. Living in a rural area significantly decreased the likelihood of wheeze by $31 \%$. Exposure to environmental tobacco smoke at home and the presence of eczema symptoms and rhinoconjunctivitis symptoms increased the likelihood of wheeze by $77 \%, 104 \%$ and $226 \%$, respectively. Only the presence of rhinoconjunctivitis symptoms increased the likelihood of severe wheeze by $107 \%$. Conclusion Wheeze appears to be an emerging public health problem in the Polokwane area. Hopefully, detailed analytical intervention studies will further explicate these results in the near future.
\end{abstract}

Keywords Wheeze - Children - Risk factors - South Africa - International Study of Asthma and Allergies in Childhood

\section{Introduction}

Asthma is the most common chronic disease among children globally $[1,2]$. Asthma is a chronic inflammatory disorder of the airways in which many cells and cellular elements play a role. The chronic inflammation is associated with airway hyperresponsiveness that leads to recurrent episodes of wheezing, breathlessness, chest tightness, and coughing, particularly at night or in the early morning. These episodes are usually associated with widespread, but variable, airflow obstruction within the lung that is often reversible either spontaneously or with treatment [2].

Asthma has physical, psychological, economical and social consequences on the quality of life of affected individuals [2]. Absence from school and days lost from work are reported as substantial social and economic consequences of asthma in studies from the Asia-Pacific region, India, Latin America, the United Kingdom, and the United States [2]. Direct costs of asthma include those from hospital admission and medication use. Affected individuals may also experience local and systemic side effects of inhaled corticosteroids during medication [2].

Apart from the increase in childhood asthma prevalence both in developed and developing nations, the Global Burden of Asthma Report also stated that over $80 \%$ of asthma deaths occur in low and lower-middle income countries [2]. The prevalence rate of asthma is higher in the Southern African 
Development Community (SADC region) than in many other regions in Africa [2]. The SADC region has 15 member states, namely: Angola, Botswana, Democratic Republic of the Congo, Lesotho, Madagascar, Malawi, Mauritius, Mozambique, Namibia, Seychelles, South Africa, Swaziland, Tanzania, Zambia and Zimbabwe. South Africa ranks 25th globally in terms of asthma prevalence and has the fifth highest number of asthma deaths among the 5-34 year olds in the world [2]. Asthma is the third most common cause of hospital admission in children in South Africa, after pneumonia and gastroenteritis [3-5]. The number of admissions to hospital for asthma has increased markedly over the last few decades in South Africa [3-5].

Medication is not the only way to control asthma. Understanding the global variation in asthma prevalence is important both for local health-care endeavors and also for gaining insight into the epidemiology of asthma. The changes in asthma prevalence are likely to be a consequence of environmental factors that are influencing the risk in genetically susceptible individuals through geneenvironment interactions [6, 7]. Most asthma deaths in South Africa occur at home, during winter and over weekends [5]. Hence the association between asthma and household conditions is important to investigate. Allergic rhinitis and eczema are also important risk factors for asthma development and exacerbation [8]. One efficient way to prevent asthma development is to control and treat allergic rhinitis and eczema from the very beginning of their inception.

The International Study on Asthma and Allergies in Childhood (ISAAC) was founded in 1992 to maximize the value of epidemiological research into asthma, eczema and allergic rhinoconjunctivitis by establishing a standardized methodology and facilitating international collaboration $[9,10]$. The ISAAC Phase I studies were conducted during 1992-1995 in 56 countries among 715,033 children between the ages of 6-7 and 13-14 years. The older group was selected to indicate the period when morbidity from asthma is common and to enable the use of self-completed questionnaires. The younger group was chosen to reflect the early childhood years, and involved parent completion of questionnaires. ISAAC Phase I studies aimed to describe the magnitude and geographic distribution of asthma, eczema and allergic rhinoconjunctivitis in as many countries as possible. This was done by using simple standardized, validated, questionnaire-based instruments [9]. ISAAC Phase II studies have already been conducted at 36 centers in 22 countries, using detailed questionnaires and objective measurements of physiological variables and indoor exposure [10,11]. Phase III involved a repeat of Phase I in about 100 centers after at least 5 years. This lag period enabled the time trends of symptom prevalence to be determined and the incorporation of new centers for the development of a more comprehensive 'world map' [12]. This phase currently involves approximately 280 centers in 106 countries. The design of Phase III is similar to that of Phase I in that the same sampling frame, method of selecting schools and method of selecting children within schools are used.

This is the fifth study that applied the ISAAC methodology in the SADC region. ISAAC Phase I and III studies were conducted in South Africa during 1995 and 2002 in the urban setting of Cape Town [13, 14]. ISAAC Phase III studies were also conducted in urban, suburban and semi-rural areas in Maputo, Mozambique during May 2004 and in Kinshasa, the Democratic Republic of Congo [15, 16]. Three of these four studies from the SADC region focused on 13- to 14-year olds and all four studies did not investigate the association between potential risk factors and asthma symptoms. Ghana, which is not located in the SADC region, is the only African country where a Phase II study has been conducted $[10,11]$.

This study is, to the best of our knowledge, the first study that investigated the association between potential risk factors and asthma symptoms in children in South Africa and in the SADC region. It is the first study from South Africa and the second study from the SADC region that focused specifically on 6- to 7-year-old children. The aims of this study were: (1) to compile information on the prevalence and potential risk factors of wheezing in previous 12 months (hereafter wheeze) and severe wheeze for 6-7-year-old children in the Polokwane area; (2) to compare results with other regions where ISAAC studies have been conducted; and (3) to contribute to the current body of knowledge regarding the prevalence and potential risk factors of eczema in children, specifically in the context of a developing country. 


\section{Methods and Procedures}

\section{Study Location}

This study was part of a bigger project that investigated the baseline prevalence rates of allergic diseases among children in the vicinity of a platinum smelter. The smelter is located $60 \mathrm{~km}$ from the Polokwane city center and several mining-related industries are found in the vicinity. This study was extended to include all areas within a $60-\mathrm{km}$ radius of the city center.

Polokwane is the capital city of Limpopo Province, the northern-most province of South Africa (Fig. 1). The population of the Polokwane municipality was 483,000 in 2001 , of whom the majority (73\%) lived in rural areas on the periphery of the municipality $[17,18]$. Limpopo is the second poorest province in the country [17], with an estimated $11 \%$ of the adult population having no formal education [18]. The Polokwane municipality is developing at a rapid pace, and the mining industry has boomed over the last decade. The municipality is therefore faced with environmental concerns and risks that are typical of those experienced by industrialized cities and many developing countries.

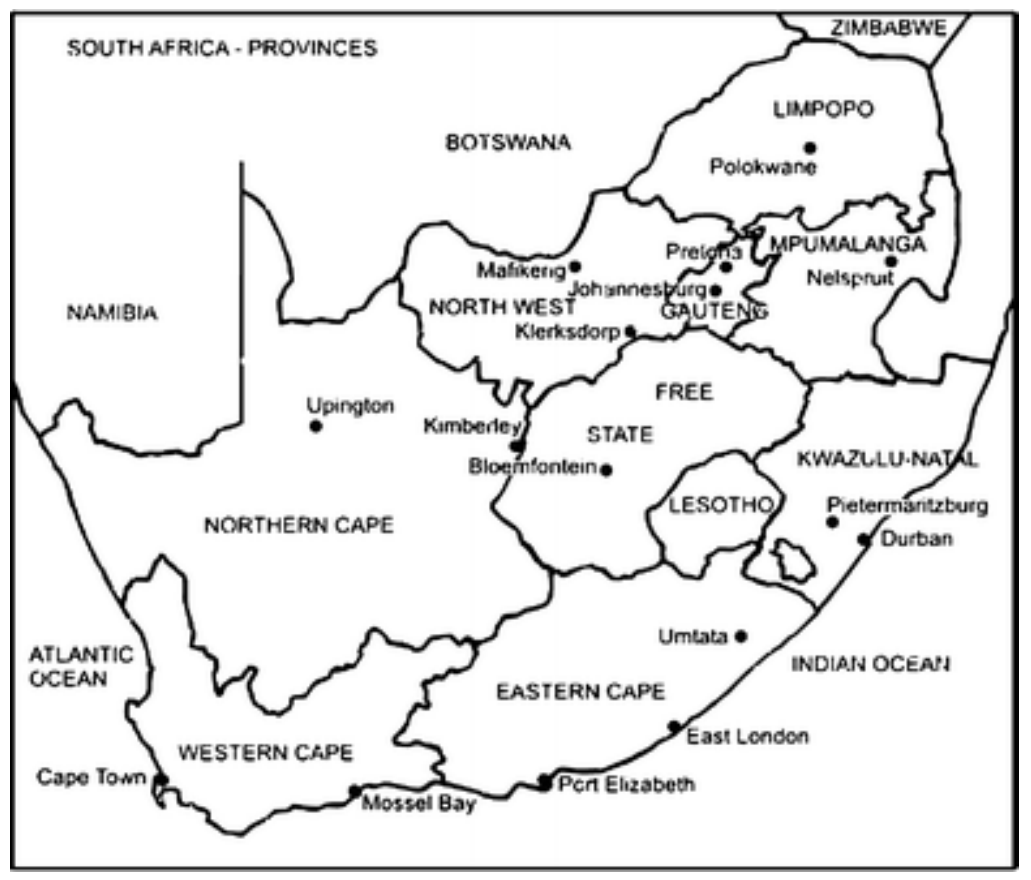

Fig. 1 Location of Polokwane and Cape Town in South Africa

Polokwane is $1,736 \mathrm{~km}$ northeast of Cape Town (Fig. 1), the location of previous South African studies that have applied the ISAAC methodology. While Cape Town is in a winter rainfall area with a fynbos biome, Polokwane is located in a summer rainfall area with a bushveld biome. ${ }^{1}$ Whereas Cape Town is at sea level and has an average summer temperature of $26^{\circ} \mathrm{C}$, Polokwane is situated $1,300 \mathrm{~m}$ above sea level, with an average summer temperature of $27^{\circ} \mathrm{C}$.

\section{Sampling and Procedures}

The study had a cross-sectional design and followed the ISAAC Phase III methodology [19]. Owing to the size of the area covered in the study, it was conducted during August 2004 (winter), October 2004 (spring) and February 2005 (summer). The questionnaire was designed to assess the prevalence of asthma symptoms, eczema symptoms and rhinoconjunctivitis symptoms, as well as to assess potential risk factors for these symptoms.

The questionnaire was translated into North-Sotho, which is the primary local language spoken by the communities in the study area. A different translator translated the questionnaire back to English in order to ensure consistency with the original. The questionnaire was also made available in English 
and Afrikaans, which are the other two languages spoken in the area. The Afrikaans version was already available from the first Cape Town ISAAC study [13].

A list of 168 schools was provided by the Limpopo Province Department of Education. Seventy-five schools were selected from the list by simple random sampling. Sixty-three schools participated in the study. Schools were contacted by telephone or fax to obtain permission for visits. Where necessary, at least three attempts were made to obtain such permission. Reasons for non-inclusion of a school were: (1) Permission was not received prior to the start of fieldwork; (2) roads were inaccessible at the time of the fieldwork; (3) the inability to locate schools because of the remoteness of their location; (4) administrative problems; (5) a school having closed down and/or (6) lack of cooperation from a school.

Questionnaires were distributed in all the Grade 1 classes of the 63 schools. Children in grade 1 are usually 6-7 years old-the target population of this study. The children were requested to take the questionnaires home for completion by their parents/guardians.

Twelve fieldworkers, who were postgraduate students from the community, were selected and attended a 1-day training session on how to undertake the study. One of the co-authors accompanied each of the six fieldwork teams on at least 1 day during the survey to ensure adherence to the protocol. The multilingual fieldworkers briefed the children on the study, distributed and collected the questionnaires at the schools and acted as liaison with the school, children and parents/guardians in case of questions of clarity.

Approval was granted by the University of Pretoria Ethics Committee and the Ministry of Education, Limpopo Province. The consent forms were sent to the parents along with the questionnaires. The fieldworkers and data capturers were instructed to keep all information confidential. Anonymity was maintained and the names of the respondents were not recorded.

\section{Definitions of Health Outcomes and Household Living Conditions}

In this study, we estimated wheeze, eczema symptoms and rhinoconjunctivitis symptoms in the previous 12 months on the basis of positive answers to the written questions outlined in Table 1. Table 1 Definitions of health outcomes

\begin{tabular}{|c|c|}
\hline Health outcomes & Questions \\
\hline Wheeze & "Has your child had wheezing or whistling in the chest in the past 12 months?" \\
\hline \multirow{4}{*}{ Severe wheeze } & "How many attacks of wheezing has your child had in the past 12 months?" \\
\hline & $\begin{array}{l}\text { "In the past } 12 \text { months, has wheezing ever been severe enough to limit your } \\
\text { child's speech to only one or two words at a time between breaths?" }\end{array}$ \\
\hline & $\begin{array}{l}\text { "In the past } 12 \text { months, how often, on average, has your child's sleep been } \\
\text { disturbed due to wheezing?" }\end{array}$ \\
\hline & $\begin{array}{l}\text { "In the past } 12 \text { months, has your child's chest ever sounded wheezy during or } \\
\text { after exercise?" }\end{array}$ \\
\hline \multirow{3}{*}{ Eczema symptoms } & $\begin{array}{l}\text { "Did your child have an itchy rash that was coming and going for at least } \\
6 \text { months? }\end{array}$ \\
\hline & “Did your child have this itchy rash at any time in the last 12 months?" \\
\hline & $\begin{array}{l}\text { "Has this itchy rash at any time affected any of the following places: the folds of } \\
\text { the elbows, behind the knees, in front of the ankles, under the buttocks, or } \\
\text { around the neck, ears, or eyes?" }\end{array}$ \\
\hline \multirow{3}{*}{$\begin{array}{l}\text { Rhinoconjuntivitis } \\
\text { symptoms }\end{array}$} & $\begin{array}{l}\text { "Has your child ever had a problem with sneezing or a runny or blocked nose, } \\
\text { when he/she did not have a cold or the flu?" }\end{array}$ \\
\hline & $\begin{array}{l}\text { "In the past } 12 \text { months, has your child had a problem with sneezing or a runny } \\
\text { or blocked nose when he/she did not have a cold or the flu?" }\end{array}$ \\
\hline & $\begin{array}{l}\text { “In the past } 12 \text { months, has this nose problem been accompanied by itchy } \\
\text { watery eyes?” }\end{array}$ \\
\hline
\end{tabular}


Children who had wheeze were considered to have severe wheeze if their parent/guardian indicated at least two of the following responses to the questions outlined in Table 1: (1) Four or more attacks in the last 12 months; (2) speech disturbance in the last 12 months; (3) more than one night of sleep disturbance in the last 12 months; and (4) wheezing with exercise in the last 12 months.

Risk factors assessed included household conditions, demographic characteristics, travel time to nearest clinic/hospital from home, and the presence of eczema symptoms and rhinoconjunctivitis symptoms (Table 2).

Table 2 Demographic characteristics, household conditions and health outcomes of the study participants $(n=2,437)$

\begin{tabular}{|c|c|c|}
\hline Variable & Total & Percentage \\
\hline \multicolumn{3}{|l|}{ Sex of child } \\
\hline Male & 1,228 & 50.4 \\
\hline Female & 1,202 & 49.3 \\
\hline Not stated & 7 & 0.3 \\
\hline \multicolumn{3}{|l|}{ 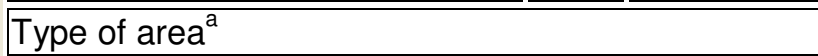 } \\
\hline Urban & 624 & 25.6 \\
\hline Rural & 1,813 & 74.4 \\
\hline \multicolumn{3}{|l|}{ Lived close to the smelter $^{\mathrm{b}}$} \\
\hline Yes & 557 & 22.9 \\
\hline No & 1,880 & 77.1 \\
\hline \multicolumn{3}{|c|}{ Time period lived in current suburb/village } \\
\hline$<3$ years & 369 & 15.2 \\
\hline$\geq 3$ years & 1,919 & 78.7 \\
\hline Other response & 149 & 6.1 \\
\hline \multicolumn{3}{|c|}{ Travel time to nearest clinic/hospital from home } \\
\hline 15 min walk or 5 min drive & 769 & 32.7 \\
\hline $1 \mathrm{~h}$ walk or $15 \mathrm{~min}$ drive & 862 & 35.4 \\
\hline$>1 \mathrm{~h}$ walk or $>30$ min drive & 658 & 27.0 \\
\hline Other response & 121 & 5.0 \\
\hline \multicolumn{3}{|l|}{ Type of house ${ }^{c}$} \\
\hline Formal & $\overline{1,752}$ & 71.9 \\
\hline Informal & 685 & 28.1 \\
\hline \multicolumn{3}{|l|}{ Cooking fuel type $^{d}$} \\
\hline Clean & 622 & 25.5 \\
\hline Combination of dirty and clean & 1,815 & 74.5 \\
\hline \multicolumn{3}{|l|}{ Having running water in house } \\
\hline Yes & 327 & 13.4 \\
\hline No & 2,038 & 83.6 \\
\hline Other response & 72 & 3.0 \\
\hline \multicolumn{3}{|l|}{ ETS exposure at home } \\
\hline Yes & 299 & 12.3 \\
\hline No & 2,009 & 82.4 \\
\hline Other response & 129 & 5.3 \\
\hline \multicolumn{3}{|c|}{ Having pets or animals in and around house } \\
\hline Yes & $\longdiv { 1 , 0 7 4 }$ & 44.1 \\
\hline
\end{tabular}




\begin{tabular}{|c||l|l||}
\hline Variable & Total & Percentage \\
\hline \hline No & 1,290 & 52.9 \\
\hline \hline Other response & 73 & 3.0 \\
\hline \hline Wheeze in previous 12 months \\
\hline \hline Yes & 273 & 11.2 \\
\hline \hline No & 1,401 & 57.5 \\
\hline \hline Other response & 763 & 31.3 \\
\hline \hline Severe wheeze in previous 12 months \\
\hline \hline Yes & 139 & 5.7 \\
\hline \hline No & 134 & 5.5 \\
\hline \hline Other response & 2,164 & 88.8 \\
\hline \hline Eczema symptoms in previous 12 months \\
\hline \hline Yes & 196 & 8.0 \\
\hline \hline No & 2,011 & 82.5 \\
\hline \hline Other response & 230 & 9.5 \\
\hline \hline Rhinoconjunctivitis symptoms in previous 12 months \\
\hline \hline Yes & 179 & 7.3 \\
\hline \hline No & 2,083 & 85.5 \\
\hline \hline Other response & 175 & 7.2 \\
\hline
\end{tabular}

aurban: Seshego and Polokwane districts, Rural: Mankweng, Bahlaloga, Maraba, Maune and Mogodumo districts

${ }^{b}$ Yes: Mogodumo and Polokwane districts, No: Mankweng, Bahlaloga, Maraba, Maune, Mogodumo and Seshego districts

'Formal: brick; informal: corrugated iron, mud, or combination with or without bricks

${ }^{d}$ Clean: gas and/or electricity; combination of clean and polluted: coal, paraffin, gas and/or electricity

\section{Data Management and Statistical Analyses}

Five data capturers were trained in how to enter the data digitally into a customized information system. The data were entered into a database set up in EPIDATA. The data capture screen mirrored the forms onto which the data had been recorded. Any changes made to the data entered into the system were done in consultation with one of the co-authors, and documented. The data were double-entered by different data capturers and the two sets of records compared, after which discrepancies were checked against the original questionnaire and corrected.

The data were extracted from EPIDATA and statistically analyzed with the statistical package STATA V9. Prevalence rates for the health outcomes and the proportion of risk factors under investigation were calculated by dividing the number of participants who responded affirmatively to a particular question by the number of questionnaires completed. This resulted in each question having a slightly different sample size.

Crude and adjusted odds ratios (OR) and 95\% confidence intervals $(\mathrm{Cl})$ were calculated to estimate the likelihood of wheeze or severe wheeze given the presence of a potential risk factor, using univariate and multivariate logistic regression analyses (LRA). Not all children who were in grade 1 $(n=3,522)$, were $6-7$ years old at the time of the survey. The data analysis was therefore restricted to those children who were 6- to 7-year-old $(n=2,876)$. Furthermore, the majority $(84.7 \%)$ of the 2,876 questionnaires were completed in North-Sotho. The data analysis was therefore also restricted to the North-Sotho group who attended 55 of the 63 schools. The ISAAC protocol stipulated that separate analyses should be conducted for different ethnic groups [9, 10]. Language was used as a proxy to indicate race, in this case North-Sotho to indicate Black/African ethnicity. English and Afrikaans are spoken by the other three race groups. Under Apartheid, South Africans were categorized into one of four socially defined race or ethnic groups: White (mainly European ancestry), Asian (Indian subcontinent ancestry), African or Black (descent primarily from one of a number of Bantu language 
groups in Southern Africa) and Coloured (general grouping, including a mixture of Black, Malay, European and indigenous Khoisan ancestry). Race is linked to both past and present access to resources, socio-economic status, and educational status.

Observations to all questions marked as "do not know", "not stated" or "other response" were set as missing. All missing values were excluded from the LRA. The introduction of the factors in the multivariate LRA used $P$-values less than 0.2 obtained in the univariate LRA, according to the methodology of binary logistic regression analysis. $P$-values less than 0.05 were considered statistically significant $[20]$.

\section{Results}

Table 2 shows the demographic characteristics and household conditions of the participants along with the 12-month prevalence rates of wheeze, severe wheeze, eczema symptoms and rhinoconjunctivitis symptoms. The 12-month prevalence rates of wheeze and severe wheeze were $11.2 \%$ and $5.7 \%$, respectively. The prevalence rates of eczema symptoms and rhinoconjunctivitis symptoms were $8.0 \%$ and $7.3 \%$, respectively.

Approximately equal numbers of girls and boys participated in the study (Table 2). The sex of seven children was not indicated in the completed questionnaires. The majority of the children lived in the rural areas (74\%), had lived in the same area for longer than 3 years $(78 \%)$ and currently lived in formal housing $(72 \%)$. The travel time to the nearest clinic/hospital was spread equally amongst the participants. Three-quarters of the children lived in houses where a combination of gas, electricity, coal and/or paraffin is used. The majority (84\%) of the children lived in houses without running water. A small percentage of children were exposed to environmental tobacco smoke (ETS) at home (12\%). More than half of the children lived in households that did not have pets and/or animals (53\%).

Table 3 shows the total for each risk and protective factor, respective odds ratios and $95 \%$ Cls. The multivariate LRA indicated that living in a rural area significantly decreased the likelihood of wheeze by $31 \%(\mathrm{OR}=0.69 ; 95 \% \mathrm{Cl}: 0.49-0.95)$. Exposure to ETS at home and the presence of eczema symptoms and rhinoconjunctivitis symptoms increased the likelihood of wheeze by $77 \%(\mathrm{OR}=1.77$; $95 \% \mathrm{Cl}: 1.21-2.58), 104 \%$ (OR $=2.04 ; 95 \% \mathrm{Cl}: 1.35-3.08)$ and $226 \%(\mathrm{OR}=3.26 ; 95 \% \mathrm{Cl}: 2.18-$ 4.87), respectively. Only rhinoconjunctivitis symptoms increased the likelihood of severe wheeze (OR $=2.07 ; 95 \% \mathrm{Cl}: 1.12-3.82)$.

Table 3 Prevalence of wheeze and severe wheeze in previous 12 months along with crude and adjusted odds ratios, by risk or protective factors

\begin{tabular}{|c|c|c|c|c|c|c|c|}
\hline Variable & $\mid$ Total $^{\mathrm{a}}$ & $\begin{array}{l}\text { Wheeze } \\
(\%)\end{array}$ & \begin{tabular}{|l} 
Crude OR \\
$(95 \% \mathrm{Cl})$
\end{tabular} & \begin{tabular}{|l|l|}
$\begin{array}{l}\text { Adjusted OR } \\
(95 \% \mathrm{Cl})\end{array}$ \\
\end{tabular} & Total $^{\mathrm{a}}$ & $\begin{array}{l}\text { Severe } \\
\text { wheeze (\%) }\end{array}$ & $\begin{array}{l}\begin{array}{l}\text { Crude OR } \\
(95 \% \mathrm{Cl})\end{array} \\
\left(95 \%{ }^{\mathrm{c}}\right.\end{array}$ \\
\hline \multicolumn{8}{|l|}{ Sex of child } \\
\hline Female & 805 & 15.0 & 1 & 1 & 121 & 50.4 & 1 \\
\hline Male & |866 & 17.6 & $\begin{array}{l}1.20(0.93- \\
1.56)\end{array}$ & $\begin{array}{l}1.12(0.84- \\
1.50)\end{array}$ & 152 & 51.3 & $\begin{array}{l}1.04(0.64- \\
1.67)\end{array}$ \\
\hline \multicolumn{8}{|c|}{ Type of area } \\
\hline Urban & 395 & 19.0 & & 1 & 75 & 52.0 & 1 \\
\hline Rural & || $1,279$ & 15.5 & \begin{tabular}{|l}
$0.78(0.58-$ \\
$1.05)$ \\
\end{tabular} & $\begin{array}{l}0.69(0.49- \\
0.95)\end{array}$ & 198 & 50.5 & \begin{tabular}{|l}
$0.94(0.55-$ \\
$1.60)$
\end{tabular} \\
\hline \multicolumn{8}{|c|}{ Lived close to the smelter } \\
\hline No & 1,292 & 16.0 & & & 207 & 51.7 & 1 \\
\hline Yes & |382 & 17.3 & $\begin{array}{l}1.09(0.81- \\
1.48)\end{array}$ & ||- & 66 & 48.5 & $\begin{array}{l}0.88(0.51- \\
1.53)\end{array}$ \\
\hline \multicolumn{8}{|c|}{ Time period lived in current suburb/village } \\
\hline$<3$ years & 268 & 18.7 & 1 & & 50 & 54.0 & 1 \\
\hline
\end{tabular}




\begin{tabular}{|c|c|c|c|c|c|c|c|}
\hline Variable & $\mid$ Total $^{\mathrm{a}}$ & \begin{tabular}{|l} 
Wheeze \\
$(\%)$
\end{tabular} & \begin{tabular}{|l|} 
Crude OR \\
$(95 \% \mathrm{Cl})$
\end{tabular} & \begin{tabular}{|l|}
$\begin{array}{l}\text { Adjusted OR } \\
(95 \% \mathrm{Cl})\end{array}$ \\
\end{tabular} & $\mid$ Total $^{\mathrm{a}}$ & \begin{tabular}{|l|} 
Severe \\
wheeze (\%)
\end{tabular} & $\begin{array}{l}\begin{array}{l}\text { Crude OR } \\
(95 \% \mathrm{Cl})\end{array} \\
\end{array}$ \\
\hline$\geq 3$ years & $\mid 1,312$ & 15.9 & \begin{tabular}{|l|}
$0.82(0.58$ \\
$1.16)$ \\
\end{tabular} & |- & 208 & 51.0 & $\begin{array}{l}0.89(0.48- \\
1.64) \\
\end{array}$ \\
\hline \multicolumn{8}{|c|}{ Travel time to nearest clinic or hospital from home } \\
\hline $\begin{array}{l}15 \text { min walk or } \\
5 \text { min drive }\end{array}$ & 536 & 17.0 & 1 & & 91 & 50.5 & 1 \\
\hline $\begin{array}{l}1 \mathrm{~h} \text { walk or } 15 \mathrm{~min} \\
\text { drive }\end{array}$ & 588 & 16.7 & \begin{tabular}{|l|}
$0.98(0.72-$ \\
$1.34)$
\end{tabular} & $\mid-$ & 98 & 42.9 & $\begin{array}{l}0.73(0.41- \\
1.30) \\
\end{array}$ \\
\hline $\begin{array}{l}>1 \mathrm{~h} \text { walk or } \\
>30 \text { min drive }\end{array}$ & 471 & 16.1 & \begin{tabular}{|l|}
$0.94(0.67-$ \\
$1.31)$
\end{tabular} & $\mid-$ & 76 & 56.6 & $\begin{array}{l}1.27(0.69- \\
2.35)\end{array}$ \\
\hline \multicolumn{8}{|l|}{ Type of house } \\
\hline Informal & 471 & 17.6 & 1 & & 83 & 55.4 & 1 \\
\hline Formal & $\mid 1,203$ & 15.8 & \begin{tabular}{|l|}
$0.88(0.66-$ \\
$1.16)$ \\
\end{tabular} & |- & 190 & 48.9 & $\begin{array}{l}0.77(0.46- \\
1.29) \\
\end{array}$ \\
\hline \multicolumn{8}{|l|}{ Cooking fuel type } \\
\hline Clean & 413 & 16.2 & 1 & & 67 & 52.2 & 1 \\
\hline $\begin{array}{l}\text { Combination of } \\
\text { dirty and clean }\end{array}$ & $\mid 1,261$ & 16.3 & \begin{tabular}{|l|}
$1.01(0.75-$ \\
$1.36)$ \\
\end{tabular} & $\mid-$ & 206 & 50.5 & $\begin{array}{l}0.93(0.54- \\
1.62) \\
\end{array}$ \\
\hline \multicolumn{8}{|c|}{ Having running water in house } \\
\hline No & 1,450 & 15.8 & 1 & & 229 & 49.3 & 1 \\
\hline Yes & 207 & 18.4 & $\begin{array}{l}1.20(0.82- \\
1.75) \\
\end{array}$ & |- & |38 & 60.5 & $\begin{array}{l}1.57(0.78- \\
3.17) \\
\end{array}$ \\
\hline \multicolumn{8}{|l|}{ ETS exposure at home } \\
\hline No & 1,410 & 14.5 & 1 & 1 & 205 & 51.7 & 1 \\
\hline Yes & 213 & 25.4 & \begin{tabular}{|l|}
$2.00(1.42-$ \\
$2.81)$
\end{tabular} & $\begin{array}{l}1.77(1.21- \\
2.58) \\
\end{array}$ & |54 & 50.0 & $\begin{array}{l}0.93(0.51- \\
1.70) \\
\end{array}$ \\
\hline \multicolumn{8}{|c|}{ Having pets or animals in and around house } \\
\hline No & 896 & 15.1 & 1 & & 135 & 52.6 & 1 \\
\hline Yes & | 764 & 17.8 & \begin{tabular}{|l|}
$1.22(0.94-$ \\
$1.58)$ \\
\end{tabular} & $\begin{array}{l}1.20(0.90- \\
1.61) \\
\end{array}$ & $\mid 136$ & 49.3 & $\begin{array}{l}0.88(0.54- \\
1.41) \\
\end{array}$ \\
\hline \multicolumn{8}{|c|}{ Eczema symptoms in previous 12 months } \\
\hline No & 1,430 & 14.3 & 1 & 1 & 205 & 50.2 & 1 \\
\hline Yes & $\mid 153$ & 30.7 & \begin{tabular}{|l|}
$2.65(1.82-$ \\
$3.85)$ \\
\end{tabular} & \begin{tabular}{|l|}
$2.04(1.35-$ \\
$3.08)$ \\
\end{tabular} & $\mid 47$ & 57.4 & $\begin{array}{l}1.34(0.71- \\
2.53)\end{array}$ \\
\hline \multicolumn{8}{|c|}{ Rhinoconjunctivitis symptoms in previous 12 months } \\
\hline No & 1,461 & 13.8 & 1 & 1 & 202 & 46.5 & 1 \\
\hline Yes & $\mid 148$ & 37.8 & \begin{tabular}{|l|}
$3.79(2.64-$ \\
$5.46)$
\end{tabular} & $\begin{array}{l}3.26(2.18- \\
4.87) \\
\end{array}$ & $\mid 56$ & 64.3 & \begin{tabular}{|l}
$2.07(1.12-$ \\
$3.82)$
\end{tabular} \\
\hline
\end{tabular}

\footnotetext{
${ }^{\text {aT }}$ Totals for each risk factor are different due to difference in missing values

${ }^{\mathrm{b}}$ The adjusted model included 1,485 participants

'The adjusted model included 258 participants and included only the variable "Rhinoconjunctivitis symptoms in previous 12 months". The adjusted OR of this variable was 2.07 (1.12-3.82), like that of the crude OR
}

\section{Discussion}

This study has provided some insight into the association between wheeze and severe wheeze and household conditions, eczema symptoms and rhinitis symptoms in children from a predominantly rural 
area in the north of South Africa. Wheeze and severe wheeze appear to be a substantial public health problem in the Polokwane area. The 12-month prevalence rate was $11.2 \%$ for wheeze and $5.7 \%$ for severe wheeze.

Asher et al. reported the 12-month prevalence rates of wheeze from ISAAC Phase I and Phase III studies [1]. These studies focused on 6-7 and 13- to 14-year-old children. The lowest 12-month prevalence rate of wheeze was $4.6 \%$ in Lithuania, and the highest was found in Costa Rica $(32.1 \%)$ during Phase I for the 6- to 7-year-old children. The lowest 12-month prevalence rate of wheeze was reported in Indonesia (2.8\%) during Phase III, and the highest was again reported in Costa Rica $(37.6 \%)$ for the younger age group. Nigeria and Mozambique are the only African countries where ISAAC Phase I and III studies had previously been conducted for both age groups [1, 15]. The 12month prevalence rate of wheeze increased in Nigeria from $4.8 \%$ in Phase I to $5.6 \%$ in Phase III for the 6 - to 7 -year-old group. The 12-month prevalence rate of wheeze was $13.3 \%$ for the younger group in Maputo, Mozambique [15].

Ait-Khaled et al. reported on the 12-month prevalence rate of wheeze in 13- to 14-year-old children from 22 centers in 16 African countries [16]. ISAAC Phase III studies were conducted in the 16 African countries. Considerable variation was observed between the prevalence rates at various centers (4.0-21.5\%). There was a large variation both between countries and between centers in the same country. Several African centers, including Cape Town, South Africa (20.3\%), Reunion Island (21.5\%), Brazzaville, Congo (19.9\%), Nairobi, Nigeria (18.0\%), Urban Ivory Coast (19.3\%) and Conakry, Guinea (18.6\%) had higher wheeze 12-month prevalence rates than almost all European countries $[1,2]$. Asthma symptoms (such as wheeze) are clearly, therefore, an emerging public health crisis in Africa. It is therefore necessary to include the younger age group in more studies in order to address risk factors earlier in life.

The type of fuel used for cooking, exposure to ETS at home and the proximity of the household to the smelter are all surrogate measures for indoor and outdoor exposure to the criteria air pollutants and various other air pollutants. The criteria air pollutants are oxides of nitrogen, ozone, particulate matter, sulfur dioxide and lead [21]. Although the debate is still ongoing on as to whether exposure to the criteria air pollutants may cause asthma and not merely exacerbate asthma symptoms [22, 23], there is sufficient evidence that ETS exposure exacerbates symptoms of asthma and that ETS exposure probably increases the likelihood of developing asthma. It was observed that exposure to ETS at home was associated with wheeze and not severe wheeze. A possible mechanism to explain the effect of air pollution on allergic diseases is that nitrogen dioxide and carbon particles interact or bind to allergen particles and thereby increase their allergenicity [24-26].

Personal exposure to a pollutant depends on the magnitude of the pollutant concentration in the exposed environment, along with the duration and time pattern of exposure [27]. Exposure to ETS and outdoor air pollution sources may be minute compared to the exposure to smoke emissions from a mixture of the 2 to $4 \mathrm{~kg}$ of dirty fuels that are used mostly indoors for cooking in each of 4.5 million households in South Africa on a daily basis $[18,28]$. It is therefore unexpected that polluting fuel use did not have a significant effect on wheeze and severe wheeze. Fuel type used for cooking may be related to socio-economic status (SES). However, unlike atopy that is more common in higher SES groups [29], the influence of SES on asthma prevalence or incidence is conflicting [30-32]. Differences in study methodologies may be one of the reasons for these conflicting findings. In contrast to the conflicting findings of whether higher SES increases asthma or wheeze prevalence, the severity level of asthma, asthma mortality, asthma hospitalizations and asthma complications are rather determined by factors associated with poverty [30, 33-36].

Although the results suggest that living in a rural area reduced the risk of wheezing by $31 \%$, the statistical power is not strong. Living in a rural area might be an indicator for SES. Studies from Africa [37, 38], India [39] and Southeast Asia [33] have reported an increase in the prevalence of allergic diseases among children living in or migrating to urban areas.

The higher prevalence of asthma in urban metropolitan areas compared with rural and farm communities may also be discussed in relation to the "hygiene hypothesis", which is currently in question [40]. There is evidence that family size has been decreasing during the last few decades in developed countries, and this change appears to be a key determinant of the increase in the atopic 
diseases in children, adolescents and adults [29]. There also appears to be a strong association between the birth order and asthma, with a higher prevalence of the disease in firstborns [41]. According to the "hygiene hypothesis", repeated infections transmitted in early childhood by older siblings, crèche and school mates could prevent atopy in children through a deviation in the immunological balance from lymphocytes $\mathrm{T}_{\mathrm{H}} 2$ to $\mathrm{T}_{\mathrm{H}} 1$ [40]. Two types of $\mathrm{T}$-helper lymphocytes have been identified, $T_{H} 1$ and $T_{H} 2$ cells. $T_{H} 2$ cells secrete cytokines interleukin-4 (IL-4), IL-5, IL-10 and IL14. These cytokines are able to induce IgE production and to activate eosinophils leading to allergic inflammation.

However, not all infections are protective. Viral and bacterial infections of the upper and lower respiratory tract can cause wheezing and can also influence the onset and severity of asthma. Viral infections are detected in $80-85 \%$ of asthma exacerbations in children [42] and $75-80 \%$ in adults [43, 44]. Rhinoviruses are responsible for approximately $60 \%$ of the respiratory viral infections, whilst influenza, parainfluenza, respiratory syncytial virus, and adenovirus are responsible for the rest. Mycoplasma pneumoniae and Chlamydia pneumoniae cause chronic inflammation of the lower respiratory tract [45-47]. The mechanisms of viral- and bacterial-induced asthma onset or exacerbations are still under investigation [48-50]. These mechanisms are complex and intersecting: infections can be the trigger of allergic asthma, allergy can favor wheezing during respiratory infections, and allergy also can modify the course of respiratory infections.

Nasal lavage samples were not collected and analyzed for viral and bacterial pathogen levels in the Polokwane study. It is thus not possible to speculate whether the association between rhinoconjunctivitis and wheezing is due to a viral or bacterial infection, and not due to a chemical air pollution-based exposure, in this study. Proxies were used for a chemical air pollution-based exposure in this study, but there are no proxies for viral or bacterial infection.

Furthermore, little is known about the extent to which chemical air pollutants can influence the course of respiratory viral infection and its associated inflammation [50]. Studies indicate that virus-induced inflammation in the upper and lower respiratory tract may be exacerbated by concurrent exposure to low levels of diesel exhaust particulate matter, nitrogen dioxide and ozone commonly encountered in indoor and outdoor environments [51,52].

Urban areas usually have higher levels of traffic-related air pollution, such as oxides of nitrogen and particulate matter, compared to rural areas. This might be another reason for the higher prevalence of asthma in urban areas compared to rural areas. Traffic-related air pollution may possibly increase the risk of allergy development and may exacerbate symptoms in particular in susceptible subgroups [5356]. Although traffic-related air pollution levels are usually higher in urban areas, it is not necessarily the case for outdoor industrial air pollution levels or indoor air pollution levels from polluting fuels used for cooking or heating. Many poor households in South Africa use polluting fuels for cooking or heating regardless of the urban/rural location or whether the household's area is electrified [57, Mathee et al. 2000, Unpublished, 58].

No significant association was observed between those children who lived close as opposed to far from the smelter. Other studies reported significant adverse effects of industrial activities on childhood asthma symptoms [59-61].

The presence of eczema symptoms was only associated with wheeze and not with severe wheeze. Eczema is often the first sign of atopy that occurs in genetically predisposed individuals [62]. Evidence is provided by a cohort study that followed asthma-free children with eczema over 4 years [63]. At the end of this period, $45 \%$ of them showed asthma-like symptoms and $35 \%$ of them were diagnosed as having asthma by a specialist. The Early Treatment of Atopic Children study evaluated the preventive effect of cetirizine administered for 18 months on the onset of asthma in children with eczema. In the placebo group 50.4\% developed asthma at a mean age of 27 months, and in those, $40 \%$ had a family history (father or mother) of asthma [64,65]. Results from this study also reinforce the importance of eczema as a risk factor for asthma. In this study $34.2 \%$ and $17.7 \%$ of the 79 participants who had eczema symptoms in the absence of rhinoconjunctivitis symptoms, also had wheeze and severe wheeze, respectively. Very few of the 2,437 participants $(6.5 \%)$ had eczema symptoms exclusively. 
Evidence that skin sensitization evokes a systemic allergic response involving the upper and lower respiratory tract, comes from an experimental study in a mouse model of allergy [66]. Ovalbumin was applied to the stripped skin of mice in order to induce dermatitis and specific IgE production. This group of mice was compared with a group where only saline was applied. The ovalbumin sensitized mice showed marked epidermal infiltration of CD3 + T cells and eosinophils. Increases in the expression of both $\mathrm{T}_{\mathrm{H}} 2$ and $\mathrm{T}_{\mathrm{H}} 1$ cytokines (IL-4, IL-5 and interferongamma (IFN- $\mathrm{y}$ )) were noted consistent with the increase of these cytokines in atopic eczema. The sensitized mice were subsequently challenged with a single exposure to inhaled ovalbumin and bronchoalveolar lavage fluid was examined. The treated mice showed a significant increase in eosinophils in the bronchoalveolar lavage fluid compared with saline-sensitized mice. The ovalbumin mice were later shown to have a tenfold greater sensitivity to methacholine than the saline group. Thus the typical airway hyperresponsiveness associated with asthma followed cutaneous sensitization in this group of mice.

Another experimental study reported that after skin sensitization, memory $T_{H} 2$ cells migrate through the circulatory system to various sites including nasal and lung mucosa and bone marrow. Inhalation of allergens results in presentation by local dendritic cells to T cells in environment rich in $T_{H} 2$ cytokines, promoting an allergic response in the airways [67]. These interactions lead to activation of eosinophils, induction of IgE production, mast cell proliferation, epithelial cell activation, mucus hypersecretion, and smooth muscle proliferation observed in asthma [68].

The association between rhinoconjunctivitis symptoms was stronger for wheeze than for severe wheeze. Epidemiological studies report that asthma and rhinitis coexist at a higher frequency than would be expected from the prevalence of each in the general population [16, 69]. In this study $53.2 \%$ and $35.5 \%$ of the 62 participants who had rhinoconjunctivitis symptoms in the absence of eczema symptoms, also had wheeze and severe wheeze, respectively. Seven percent, $3.2 \%$ and $2.5 \%$ of the 2,437 participants had exclusively wheeze, exclusively severe wheeze and exclusively rhinoconjunctivitis symptoms, respectively. Evidence for a link between the upper and lower airway is also strengthened by various studies that reported a reduction in asthma symptoms after treatment of rhinitis [69].

\section{Limitations}

There are some important limitations in this study, which should be taken into account in the interpretation of the results. First, the study had a cross-sectional design, like all the other ISAAC studies.

Second, the extent to which the findings from the data can be generalized is determined by the nonresponse rate. The response rate is difficult to estimate as no record was kept about the number of questionnaires distributed in relation to the number of questionnaires completed and returned. As most of the schools do not have either an official or unofficial class list, it was also not possible to retrospectively estimate the response rate based on the number of questionnnaires returned. Despite the absence of a response rate, the Polokwane data were included in the ISAAC database, as the ISAAC committee also considers other data qualities [16]. This study focused only on those children who attended school and participated in the survey on the day the fieldworkers visited the school. It was not possible to trace those children who were absent. One of the co-authors who conducted the fieldwork assured the other co-authors that most of the children were present at the time of the fieldwork. The feeding scheme in the primary schools encourages parents to keep their children in school as it provides a very important meal for the children. We are confident that the school attendance was high during the study. Thus the bias that might be introduced by non-response is assumed to be relatively low for this study.

Third, reliance on self-reported data does include a risk of misclassification of disease and exposure status resulting in statistical significance arising by chance. No quantitative exposure assessment was conducted during this study, such as location, frequency and duration of fuel use for cooking; reporting on number of cigarettes smoked at home per day; source apportionment or industrial air pollution measurements. Many households in South Africa in general use a combination of cooking and heating fuels. The calculated effects may be underestimated if the use of high polluting fuels (coal) are considered exclusively and not in combination with paraffin, gas and/or electricity. The 
effects may also be underestimated when medium polluting fuels (paraffin) are used exclusively and not in combination with gas and/or electricity. However, none of the households under investigation used coal or paraffin exclusively. It is recommended that future studies should include a question on type of fuels use for heating. Exposure to smoke from polluting fuels during heating lasts longer than exposure during cooking.

Fourth, recall bias may also be present. While a 12-month period may not be a long period to recall episodes of severe wheeze, it could be for the other milder symptoms.

Fifth, other factors not recorded in this study that may contribute to wheeze and severe wheeze included: family history of asthma; mother's smoking status; allergens such as pollen, dust mites, fungal spores; birth weight; duration of breast feeding; stress and violence, body mass index, frequency and duration of viral or bacterial respiratory tract infections as well as the likelihood of HIV infection within the sample, given South Africa's high HIV prevalence.

Excluding these risk factors from the analysis might introduce bias (differential or nondifferential). Thus the direction of bias on the calculated association measures is not easy to predict. As the association between these excluded risk factors and those investigated in this study is not available from the literature, it is impossible to predict the direction of the potential bias on the association measure.

Despite these limitations, we think that our study contributes to existing literature because few data are available about the prevalence of asthma symptoms, rhinitis symptoms, and eczema symptoms in rural marginalized areas in South Africa. This baseline data provides public health practitioners and health service planners an opportunity to improve services, health promotion and serve as a benchmark for future prevalence studies. In order to improve health for the South African population through epidemiological studies, it is imperative that future studies on asthma, rhinitis, and eczema risk factor investigation should attempt to minimize systematic and random errors, and subsequently strengthen their validity and accuracy.

Acknowledgements This survey was part of a bigger project. It was commissioned and financed by Anglo Platinum and managed by SE Solutions (Pty) Ltd. The School of Health Systems and Public Health from the University of Pretoria conducted this survey by following the International Study of Asthma and Allergies in Childhood (ISAAC) protocol. All data from this study are the property of Anglo American Platinum Corporation, ISAAC and the University of Pretoria. Gratitude is expressed towards everybody who completed questionnaires, the school principals and the Education Department of the Limpopo Province for giving permission to conduct this study, the fieldworkers, the data capturers and Annemieke van Middelkoop for her assistance during the data processing stages.

\section{References}

1. Asher, M. I., Montefort, S., Björkstén, B., Lai, C. K. W., Strachan, D. P., Weiland, S. K., Williams, H., \& the ISAAC Phase Three Study Group. (2006). Worldwide time trends in the prevalence of symptoms of asthma, allergic rhinoconjunctivitis, and eczema in childhood: ISAAC phases one and three repeat multicountry cross-sectional surveys. Lancet, 368, 733-743.

2. Masoli, M., Fabian, D., Holt, S., \& Beasley, R. (2004). Global burden of asthma report. Developed for global initiative for asthma.

3. Ehrlich, R. I., \& Weinberg, E. G. (1994). Increase in hospital admissions for acute childhood asthma in Cape Town, 1978-1990. South African Medical Association, 84, 263-266.

4. MacIntyre, U. E., de Villiers, F. P. R., \& Owange-Iraka, J. W. (2001). Increase in childhood asthma admissions in an urbanising population. South African Medical Association, 91(8), 667-671. 
5. Zar, H. J., Stickells, D., Toerien, A., Wilson, D., Klein, M., \& Bateman, E. D. (2001). Changes in fatal and near-fatal asthma in an urban area of South Africa from 1980-1997. The European Respiratory Journal, 18, 33-37.

6. Simpson, A., \& Custovic, A. (2007). Genetic and environmental influences on childhood asthma. Current Opinion in Allergy and Clinical Immunology, 20(1), 4-5.

7. D'Amato, G., Liccardi, G., D'Amato, M., \& Cazzda, M. (2002). Outdoor air pollution, climatic changes and allergic bronchial asthma. The European Respiratory Journal, 20, 763-776.

8. Bousquet, J., Van Cauwenberge, P., \& Khaltaev, N. (2001). Allergic rhinitis and its impact on asthma. The Journal of Allergy and Clinical Immunology, 108, S147-S334.

9. Asher, M. I., Keil, U., Anderson, H. R., Beasley, R., Crane, J., Martinez, F., Mitchell, E. A., Pearce, N., Sibbald, B., Stewart, A. W., Strachan, D., Weiland, S. K., \& Williams, H. C. (1995). International Study of Asthma and Allergies in Childhood (ISAAC): Rationale and methods. The European Respiratory Journal, 8, 483-491.

10. ISAAC. (1998). International Study of Asthma and Allergies in Childhood (ISAAC) Methodology.

11. Weiland, S. K., Björkstén, B, Brunekreef, B., Cookson, W. O., von Mutius, E., \& Strachan, D. P. (2004). The international study of asthma and allergies in childhod phase II study group. Phase II of the international study of asthma and allergies in childhood (ISAAC II): Rationale and methods. The European Respiratory Journal, 24, 406-412.

12. Ellwood, P., Asher, M. I., Beasley, R., Clayton, T. O., Stewart, A. W., \& the ISAAC Steering Committee. (2005). The International Study of Asthma and Allergies in Childhood (ISAAC): Phase Three rationale and methods. The International Journal of Tuberculosis and Lung Disease, 9(1), $10-16$.

13. Mercer, M. J., Joubert, G., Ehrlich, R. I., Nelson, H., Poyser, M. A., Puterman, A., \& Weinberg, E. G. (2004). Socioeconomic status and prevalence of allergic rhinitis and atopic eczema symptoms in young adolescents. Pediatric Allergy and Immunology, 15(3), 234-241.

14. Zar, H. J., Ehrlich, R. I., \& Weinberg, E. G. (2004). The prevalence of asthma, allergic rhinitis and atopic eczema (ISAAC phase 3 study) in adolescents in Cape Town and comparison with ISAAC 1. Current Opinion in Allergy and Clinical Immunology, 17, 140.

15. Mavale-Manuel, S., Joaquim, O., Macome, C., Almeida, L., Nunes, E., Daniel, A., Malichocho, J., Pedro, A., Bandeira, S., Eduardo, E., Maciel, L., Constance, E., Marques, S., Tembe, A., de Blic, J., \& Annesi-Maesano, I. (2007). Asthma and allergies in schoolchildren of Maputo. Allergy, 62, 265-271.

16. Ait-Khaled, N., Odhiambo, J., Pearce, N., Adjoh, K. S., Maesano, I. A., Benhabyles, B., Bouhayad, Z., Bahati, E., Camara, L., Catteau, C., El Sony, A., Esamai, F. O., Hypolite, I. E., Melaku, K., Musa, O. A., Ng'ang'a L, Onadeko, B. O., Saad, O., Jerray, M., Kayembe, J. M., Koffi, N. B., 
Khaldi, F., Kuaban, C., Voyi, K., M'Boussa J, Sow, O., Tidjani, O., \& Zar, H. J. (2007). Prevalence of symptoms of asthma, rhinitis and eczema in 13- to 14-year-old children in Africa: the international study of asthma and allergies in childhood phase III. Allergy, 62(3), 247-258.

17. Polokwane Municipal Level Analysis, Polokwane City.

18. Statistics South Africa. Census (2001). Census in brief. Pretoria: Statistics South Africa. 20037.

19. ISAAC. (1998). International Study of Asthma and Allergies in Childhood (ISAAC), Phase Three Manual.

20. Hosmer, D. W., \& Lemeshow, S. (2000). Applied logistic regression (2 ed.). New York: John Wiley and Sons.

21. World Health Organization Regional Office for Europe. (2000). Air quality guidelines for Europe (2nd ed.). Copenhagen: WHO Regional Publications, European Series, No. 91.

22. Institute of Medicine, Committee on the Assessment of Asthma and Indoor Air. (2000). Clearing the air: Asthma and indoor air exposures. Washington, DC: National Academy Press.

23. WHO. (2003). Health aspects of air pollution with particulate matter, ozone and nitrogen dioxide. Report on a WHO Working Group. Bonn: World Health Organization.

24. Ruffin, J., Liu, M. Y., Sessoms, R., Banerjee, S., \& Banerjee, U. C. (1986). Effects of certain atmospheric pollutants $\left(\mathrm{SO}_{2}, \mathrm{NO}_{2}\right.$ and $\left.\mathrm{CO}\right)$ on the soluble amino acids, molecular weight and antigenicity of some airborne pollen grains. Cytobios, 46, 119-129.

25. Emberlin, J. (1995). Interaction between air pollutants and aeroallergens. Clinical and Experimental Allergy, 25(Suppl 3), 33-39.

26. Knox, R. B., Suphioglu, C., Taylor, P., Desai, R., Watson, H. C., Peng, J. L., \& Bursill, L. A. (1997). Major grass pollen allergen Lol $p 1$ binds to diesel exhaust particles: implications for asthma and air pollution. Clinical and Experimental Allergy, 27, 246-251.

27. Ryan, P. B. (1991). An overview of human exposure modeling. Journal of Exposure Analysis and Environmental Epidemiology, 1, 453-474.

28. Brouwer, R., \& Falcão M. P. (2004). Wood fuel consumption in Maputo, Mozambique. Biomass and Bioenergy, 27, 233-245.

29. Strachan, D. P. (2000). Family size, infection and atopy: The first decade of the "hygiene hypothesis". Thorax, 55(Suppl 1), S2-S10.

30. Mielck, A., Reitmeir, P., \& Wjst, M. (1996). Severity of childhood asthma by socioeconomic status. International Journal of Epidemiology, 25, 388-393. 
31. Rona, R. J. (2000). Asthma and poverty. Thorax, 55, 239-244.

32. Poyser, M. A., Nelson, H., Ehrlich, R. I., Bateman, E. D., Parnell, S., Putermanz, A., \& Weinberg, E. (2002). Socioeconomic deprivation and asthma prevalence and severity in young adolescents. The European Respiratory Journal, 19, 892-898.

33. Goh, D. Y., Chew, F. T., Quek, S. C., \& Lee, B. W. (1996). Prevalence and severity of asthma, rhinitis, and eczema in Singapore schoolchildren. Archives of Disease in Childhood, 74, 131-135.

34. Strachan, D. P., Anderson, H. R., Limb, E. S., O'Neill, A., \& Wells, N. (1994). A national survey of asthma prevalence, severity, and treatment in Great Britain. Archives of Disease in Childhood, 70, 174-178.

35. Ehrlich, R. I., \& Bourne, D. E. (1994). Asthma deaths among coloured and white South Africans: 1962-1988. Respiratory Medicine, 88, 195-202.

36. Claudio, L., Tulton, L., Doucette, J., \& Landrigan, P. J. (1999). Socioeconomic factors and asthma hospitalization rates in New York City. The Journal of Asthma, 36, 343-350.

37. Steinman, H. A., Donson, H., Kawalski, M., Toerien, A., \& Potter, P. C. (2003). Bronchial hyperresponsiveness and atopy in urban, periurban and rural South African children. Pediatric Allergy and Immunology, 14, 383-393.

38. Odhiambo, J. A., Ng'ang'a L. W., Mungai, M. W., Gicheha, C. M., Nyamwaya, J. K., Karimi, F, et al. (1998). Urban-rural differences in questionnaire-derived markers of asthma in Kenyan school children. The European Respiratory Journal, 12, 1105-1112.

39. Chakravarthy, S., Singh, R. B., Swaminathan, S., \& Venkatesan, P. (2002). Prevalence of asthma in urban and rural children in Tamil Nadu. The National Medical Journal of India, 15, 260-263.

40. Liu, A. H., \& Murphy, J. R. (2003). Hygiene hypothesis: fact or fiction? The Journal of Allergy and Clinical Immunology, 111, 471-478.

41. Ball, M. T., Castro-Rodriguez, J. A., Grith, K. A., Holberg, C. J., Martinez, F. D., \& Wright, A. L. (2000). Siblings, day-care attendance and the risk of asthma and wheezing during childhood. The New England Journal of Medicine, 343, 538-543.

42. Chauhan, A. J., Inskip, H. M., Linaker, C. H., Smith, S., Schreiber, J., Johnston, S. L., \& Holgate, S. T. (2003). Personal exposure to nitrogen dioxide $\left(\mathrm{NO}_{2}\right)$ and the severity of virus-induced asthma in children. Lancet, 361, 1939-1944. 
43. Wark, P. A., Johnston, S. L., Moric, I., Simpson, J. L., Hensley, M. J., \& Gibson, P. G. (2002). Neutrophil degranulation and cell lysis is associated with clinical severity in virus-induced asthma. The European Respiratory Journal, 19, 68-75.

44. Grissell, T. V., Powell, H., Shafren, D. R., Boyle, M. J., Hensley, M. J., Jones, P. D., Whitehead, B. F., \& Gibson, P. G. (2005). Interleukin-10 gene expression in acute virus-induced asthma. American Journal of Respiratory and Critical Care Medicine, 172, 433-499.

45. Kraft, M., Cassell, G. H., Henson, J. E., Watson, H., Williamson, J., Marmion, B. P., Gaydos, C. A., \& Martin, R. J. (1998). Detection of Mycoplasma pneumoniae in the airways of adults with chronic asthma. American Journal of Respiratory and Critical Care medicine, 158, 998-1001.

46. Martin, R. J., Kraft, M., Chu, H. W., Berns, E. A., \& Cassell, G. H. (2001). A link between chronic asthma and chronic infection. The Journal of Allergy and Clinical Immunology, 107, 595-601.

47. Von Hertzen, L. C. (2002). Role of persistent infection in the control and severity of asthma: Focus on Chlamydia pneumoniae. The European Respiratory Journal, 19, 546-556.

48. Johnston, S. L. (2007). Innate immunity in the Pathogenesis of virus-induced asthma exacerbations. Proceedings of the American Thoracic Society, 4, 267-270.

49. Brunetti, L., Colazzo, D., Francavilla, R., Tesse, R., De Sario, V., Lorè M, \& Armenio, L. (2007). The role of pulmonary infection in pediatric asthma. Allergy and Asthma Proceedings, 28, 190193.

50. Tan, W. C. (2005). Viruses in asthma exacerbations. Current Opinion in Pulmonary Medicine, 11, 21-26.

51. Spannhake, E. W., Reddy, S. P., Jacoby, D. B., Yu, X. Y., Saatian, B., \& Tian, J. (2002).

Synergism between rhinovirus infection and oxidant pollutant exposure enhances airway epithelial cell cytokine production. Environ Health Perspect, 110, 665-670.

52. Harrod, K. S., Jaramillo, R. J., Rosenberger, C. L., Wang, S. Z., Berger, J. A., McDonald, J. D., \& Reed, M. D. (2003). Increased susceptibility to RSV infection by exposure to inhaled diesel engine emissions. American Journal of Respiratory Cell and Molecular Biology, 28(4), 451-463.

53. Heinrich, J., \& Wichmann, H. E. (2004). Traffic related pollutants in Europe and their effect on allergic disease. Current Opinion in Allergy and Clinical Immunology, 4, 341-348.

54. Annesi-Maesano, I., Moreau, D., Caillaud, D., Lavaud, F., Le Moullec, Y., Taytard, A., Pauli, G., \& Charpin, D. (2007). Residential proximity fine particles related to allergic sensitisation and asthma in primary school children. Respiratory Medicine, 101(8), 1721-1729. 
55. Brauer, M., Hoek, G., Smit, H. A., de Jongste, J. C., Gerritsen, J., Postma, D. S., Kerkhof, M., \& Brunekreef, B. (2007). Air pollution and development of asthma, allergy and infections in a birth cohort. The European Respiratory Journal, 29(5), 879-888.

56. Pattenden, S., Hoek, G., Braun-Fahrländer C, Forastiere, F., Kosheleva, A., Neuberger, M., \& Fletcher, T. (2006). $\mathrm{NO}_{2}$ and children's respiratory symptoms in the PATY study. Occupational and Environmental Medicine, 63(12), 828-835.

57. Terblanche, P. (1998). Vaal triangle air pollution health study—Bibliography, summary of key findings and recommendations. Prepared for the South African Medical Research Council, ISBN 1087 4826-89-7.

58. Banks, L., Mlomo, B., \& Lujabe, P. (1996). Social determinants of energy use in low income households in metropolitan areas (Eastern Cape). Pretoria, South Africa: South African Government Chief Directorate: Energy.

59. Schaumann, F., Borm, P. J., Herbrich, A., Knoch, J., Pitz, M., Schins, R. P., Luettig, B., Hohlfeld, J. M., Heinrich, J., \& Krug, N. (2004). Metal-rich ambient particles $\left(\mathrm{PM}_{2.5}\right)$ cause airway inflammation in healthy subjects. American Journal of Respiratory and Critical Care Medicine, 170(8), 898-903.

60. Heinrich, J., Hoelscher, B., Wjst, M., Ritz, B., Cyrys, J., \& Wichmann, H. (1999). Respiratory diseases and allergies in two polluted areas in East Germany. Environ Health Perspect, 107, 5362.

61. Dodge, R. (1983). The respiratory health and lung function of Anglo-American children in a smelter town. The American Review of Respiratory Disease, 127(2), 158-161.

62. Spergel, J. M., \& Paller, A. S. (2003). Atopic dermatitis and the atopic march. The Journal of Allergy and Clinical Immunology, 112(6 Suppl), S118-S127.

63. Valero, A., Serrano, C., Valera, J. L., Barbera, A., Torrego, A., Mullol, J., \& Picado, C. (2005). Nasal and bronchial response to exercise in patients with asthma and rhinitis: the role of nitric oxide. Allergy, 60, 1126-1131.

64. Hellings, P. F., \& Fokkens, W. J. (2006). Allergic rhinitis and its impact on otorhinolaryngology. Allergy, 61, 656-664.

65. Bousquet, J., Anto, J. M., Bachert, C., Bousquet, P. J., Colombo, P., Crameri, R., Daeron, M., Fokkens, W., Leynaert, B., Lahoz, C., Maurer, M., Passalacqua, G., Valenta, R., van Hage, M., \& Van Ree, R. (2006). Factors responsible for differences between asymptomatic subjects and patients presenting an IgE sensitization to allergens. A GA2LEN project. Allergy, 61, 671-680.

66. Spergel, J. M., Mizoguchi, E., Brewer, J. P., Martin, T. R., Bhan, A. K., \& Geha, R. S. (1998). Epicutaneous sensitization with protein antigen induces localized allergic dermatitis and 
hyperresponsiveness to methacholine after single exposure to aerosolized antigen in mice. The Journal of Clinical Investigation, 101, 1614-1622.

67. Lambrecht, B., Carro-Muino, I., Vermaelen, K., \& Pauwels, R. (1999). Allergeninduced changes in bone-marrow progenitor and airway dendritic cells in sensitized rats. American Journal of Respiratory and Critical Care Medicine, 20, 1165-1174.

68. Herrick, C. A., \& Bottomly, K. (2003). To respond or not to respond: T cells in allergic asthma. Nature Reviews. Immunology, 3, 405-412.

69. Jani, A. L., \& Hamilos, D. L. (2005). Current thinking on the relationship between rhinosinusitis and asthma. The Journal of Asthma, 42(1), 1-7.

\section{Footnotes}

${ }^{1}$ Fynbos is a unique vegetation type found in a small belt of the Western Cape Province, South Africa. The Fynbos biome is dominated by woody or herbaceous shrubs. The name fynbos is Afrikaans for fine bush and refers to the fine, needle-like leaves of many fynbos species. The majority of the plants are evergreen hard-leaf plants. Three of the characteristic fynbos plant families are proteas, ericas and restios. The Bushveld is a tropical savanna vegetation type, with grassed plains that are interspersed with dense clusters of tall shrubs, Acacia and/or Baobab trees. The grasses are generally tall and turn yellow or brown in winter. 